\title{
The State, Local 'Public' and the Politics of Taxation in Africa
}

\author{
Taiwo A. Olaiya, Ph.D; LL.B \\ Department of Public Administration Obafemi Awolowo University Ile-Ife, Nigeria
}

\begin{abstract}
This paper investigated the myriad conditions and circumstances that predispose groups to challenge or undermine the capacity of some states in Africa to impose taxes. It focused on the complex relationships that are evolving at the generic level between state-society, particularly how informal institutions and communitybased alliances are positioning themselves to deflect or negate the trajectory of illegitimacy and dearth of good governance in the states. Although less acknowledged in the comparative analysis of public administration in the developing countries, the paper established that, in some states of Africa, the centrality of taxation to good governance- encompassing the capacity, responsiveness and accountability of government- can no longer be underestimated. In order to give empirical content to the discourse, the study illustrates the issues raised with examples drawn from Nigeria.
\end{abstract}

\section{Introduction}

In most developing countries, the problem of revenue generation has persisted- and in many instances assumed greater urgency- at the same time that the shocks of the latest global financial market crisis are compounding capacity to rescue their already ailing national economies. Yet, without the ability to raise revenues effectively, governments are limited in the extent to which they can provide security, meet basic needs, and foster economic development. Several reasons can be deduced for these scenarios. First, the tax base of many African countries is either lean or skewed towards an overwhelming dependence on natural resources whose international market prices are routinely unstable. Second, because a lion share of economic activities on the continent occurs within the often opaque and poorly regulated informal sector most tax administration agencies have not been able to creatively and adequately capture them for the purpose of taxation. A related point is that even those who should ordinarily be taxable because they operate within the 'formal' sector (e.g. government contractors and service-providers) find creative ways to escape the obligation of paying tax through outright evasion or underpayment. At the institutional level, the asphyxiation of the enabling environment for taxation: tax administration agencies routinely lack the enabling laws and regulations to aid the exercise of their statutory functions; lack the capacity to impose and extract commensurate taxes from individuals and corporate bodies; and in other instances, abet fraudulent tax reporting through deliberate misrepresentation or concealment of essential information (Ali-Naskea, 2008; Olaiya, 2012).

Underlying the challenges of declining public revenue through taxation is the erosion of trust (and widening disconnect) between the citizens and those who govern them. Paradoxically, this trend is becoming evident at the same time that many countries have made the slow (and often painful) transition from military/one-party autocratic regimes to a semblance of multiparty civilian democracy: with the expectation that the new dispensation would meet and satisfy the yearnings and aspirations of the citizens. On the contrary, an invidious crisis of governance is festering (in some instances, deepening) in those countries: with concern that a reversal in governance 'fortunes' might be imminent. The key assumption underlying this paper, therefore, is that the erosion of trust is having far-reaching implications on the social contract that should exist between the people and those who govern them; and that this is at the root of the growing discontent on the part of the citizens as reflected in their unwillingness to finance the state. Studies have established the link between the provision and expansion of public goods on the part of governments and willingness by citizens to pay tax: when people see that their taxes can go a long way in providing/improving social infrastructures the willingness to pay taxes increases (Olaiya, 2012; Liou and Musgrave, 2013; Ahmadov, 2014). This paper thus investigates the sundry ways that governments are responding to the growing public apathy towards taxation.

In Nigeria, alongside this trend is the proliferation of communal institutions operating as trade unions, pressure groups and communal institutions that are now making demands on government for improvement in the provision of social infrastructures; increasingly as a minimum condition for their 'members' to acquiesce with government on payment of taxes (Duruji, 2010). Drawing from the strength and local capacities of their members vis-à-vis competing political interests, these community-based groups are also able to negotiate reduction or outright non-payment of statutory rates, fines, taxes, trade permits, etc,. For some, the groups have been able to mobilise their members to protest, embark on strike actions, picketing government offices, in order to drive home their points (NIALS, 2010). 
There is thus the need to interrogate the reasons for the proliferation of mostly informal, sometimes amorphous, community-based institutions, and why they mobilize their members to resist payments as a clever demand for good governance. As Olaiya (2012) argued, compliance for payment of taxes in Nigeria can seldom be guaranteed except when people need the tax clearance/cirtificate for political purposes or as license for access to government patronage or public goods. Thus, while their actions may not be altogether 'illegal' within the narrow definition of 'tax evasion', they tend to provoke a scholarly debate as to what have been its cumulative effects on the revenue capacity of the state as well as the ability to deliver on promised democratic dividends. In contemplating the diverse implications of this trend in Nigeria, in particular, it has become pertinent to examine what have been the state responses to its growing incapacity to widen the revenue base, in order to generate more revenue to provide and expand social infrastructures to 'win' back the confidence of the citizens. Rather than pressurize the citizens by issuing targets to revenue-generating agencies, what variety other strategies can the government adopt to 'convince' the citizens to finance their governments?

In the light of the later issues, a key goal of this paper is to understand the theoretical and policy implications of the variety of community-based tax evasion strategies-- especially in view of the fact that it is pretty difficult to generalize that the activities of such groups would produce the same result across board. What creative ways have citizens themselves mobilized to respond to pressures from the state, or to negate them? At what point would it be impossible for citizens to get round the state? What kinds of alliances are evident; either among individuals or groups or pooled interests in terms of re/engaging the state? What roles does the state play, by omission or commission, in allowing such society-based alliances to thrive? At what point would citizens make a cognitive shift from evasion to the denial of obligation to the state in respect of taxation? What are the functional implications on governance of the proliferation of trade unions, civil-society groups, and communal interest institutions, not necessarily to evade tax within a strict legal purview but to reduce the collateral impact of official taxes? In effect, to what extent does the 'gang up' against the state a kind of panacea to festering governance crisis in Africa?

\section{Theoretical Framework}

The overarching conceptual framework for this paper is derived from two important genre of social analysis. They are the sociological analysis of taxation and public finance, known as fiscal sociology, developed by Goldscheid and Schumpeter in the early $20^{\text {th }}$ century. Fiscal sociology — or Finanzsoziologie as the German name reads - has an impressive pedigree, tracing its ancestry back to the flourishing academic milieu of Mitteleuropa in the first three decades of the twentieth century (Miller, 2007). The term was coined by the Austrian academic Rudolf Goldscheid, in 1917 and it was picked up in 1918 by Joseph Schumpeter who in his classic essay "The Crisis of the Tax State" recommended an investigation of fiscal history with the following words: "He who knows how to listen to its message here discerns the thunder of world history more clearly than anywhere else" (Miller, 2007). Practically, the simplest version of the fiscal sociologists' argument is that the character of the state depends upon the character of the public finances.

Fiscal sociology addresses the importance of the emergence of an organized system of tax collection as a means of not only funding government but as veritable harbinger for good governance (Backhaus, 2002). The core of Goldscheid and Schumpeter's arguments is that once revenue source(s) that is prone to 'pillage and plunder' were abandoned in favour of tax collection, the fundamental elements of disconnect of societies, governments and markets began to emerge (Mumford, 2008). The proponents of fiscal sociology could therefore be said to have argued that the roots of modern governmental conflict and decision-making can be traced back to the inception of a country's tax system (Mumford, 2008). He argued that analyses of the political-economy of revenue collection influences patterns of governmental spending on public goods, and reveal insights about the enduring nature of government that surpass transient characteristics such as political affiliation of the governing party. He submitted that the issue at stake is the ordering of human relationships, particularly the question of which financial setup provides for the existence of a well-working commonwealth.

There is no doubt that Goldscheid and Schumpeter harbored great expectations on behalf of fiscal sociology. However, the genre more or less fell into oblivion fter the 1920s. An attempt to revive it has recently been carried out by Moore (2004) in the article "Revenues, State Formation, and the Quality of Governance in Developing Countries." Moore's focal point is the so-called fiscal (social) contract proposition: that there is a causal connection between (1) the dependence of governments on broadly levied taxes, rather than other sources of revenue, and (2) the existence of the kinds of binding constraints on governments and institutionalised political representation that constitute the foundations of liberal democracy. Very crudely, relative to other types of states, tax states will tend toward accountable, representative government. (Pp.298299)

With regards to this study, an important hypothesis could be deciphered: that a strong historical relationship - most probably causal but certainly symptomatic - exists between the sustainability of effective taxation and the revitalisation of burden of governance. John Carteret, one of the great seventeenth-century 
English statesmen, explained it prosaically in his statement that "the Security of our Liberties is not in the Laws but by the Purse being in the Hands of the People" (Miller, 2007:4). The political approach focused on the inter-relationships between tax systems and political regimes. The approach emphasized that taxation is not simply a technical question, it is inherently political. Proponents of the political approach have a diversity of concerns. The point of convergence is an emphasis on making political analysis central to the tax policy debate (Campbell, 1993). Within this general category of political approaches to taxation, there are perhaps three main sub-approaches: societal institutional, and political developmental.

The societal approach is political in the most straightforward and commonplace sense of the term: the study of particular processes and sequences with an emphasis on the clash of interests - "winners", "losers" and the political tactics they employ. This approach usually focuses on the relative power of different social actors, and the ways in which taxation structures are the outcomes of social conflict. The major implication of the societal sub-approach is that an efficient, equitable and effective tax has to be in the interests of important social actors. Reforms that produce such a tax system will not be politically feasible if distributional effects cannot be anticipated, let alone negotiated. Ascher (1989:414) wrote that political feasibility thus depends on the elaboration of detailed analysis and discussion that predicts distributive outcomes. This allows 'the limitation of risk so that affected groups will be willing to bear some additional - but predictably contained - costs'.

Another germane aspect of the societal sub-approach is the effective mobilisation of the stakeholders economic and/or political — and the masses. The interests of stakeholders influence the likelihood that reform will occur and the shape that it takes. Influential segments of society must be convinced that their lot would be better and that increased focus on tax revenue would ensue improved governance. Lledo et al (2004:9) submitted that convincing these powerful elements, whose primary acceptance to pay more taxes matters, may not be an easy task in environments characterised by poor services and widespread corruption. For instance, the weaker segments of society may have less wealth to contribute, but it is equally important that they are well mobilised. The mass support they could provide for the reform could bring about the necessary political impetus or even intimidation on the influential segment, thus pushing it in a progressive direction (Lledo et al, 2004:9). Bureaucratic cadres are also important. Lledo et al (2004:9) particularly stated that in situations where bureaucrats resist reform or not properly carried along, reforms are doomed. Thus, even with best efforts and intentions, establishing independent revenue authorities with necessary devolution of power is not enough. Problems may still beset the reforms as bureaucrats fail to reform their behaviour or simply refuse to use new institutions to curb clientelism and corrupt practices.

The institutional approach proposes a second best solution in the design of institutions. As Buchanan (1987) pointed out, institutions bound the interaction of social forces, define which interests will be represented, and can bias the outcome of social interaction. This powerful insight increased attention to the incentives built into institutions - such as presidential and parliamentary systems, electoral cycles, powerful central banks, finance ministries, autonomous revenue authorities, and decentralisation (Besley and Case, 2002). Lledo et al (2004:10) observed that the constitutive effects of the societal and institutional approaches highlight the way actors come together in systems of political representation and are limited by state institutions, themselves the product of historical contexts. Thus, taxation as a powerful instrument of political stabilization and governance is understood to emerge from the pressures of social forces, but only after they have been filtered by formal and informal institutions of the state (Lledo et al, 2004).

The third political sub-approach is the political development approach, which reverses the direction of causal enquiry. Instead of asking how existing political forces and institutions shape tax structures and tax reforms to effect changes in governance, the political development approach suggests that institutions of taxation affect the type and quality of governance, or the "political development" of particular countries (Brennan and Buchanan, 1980; Bates, 1989). From the perspective of the political development approach, taxation is as much a part of 'a social contract between state and society as it is a mechanism of financing government'. Lledo et al (2004:11) wrote that a state with high levels of political legitimacy can depend on citizens' quasi-voluntary compliance to contribute to public goods (quasi-voluntary because there is always some element of coercion). As a result, states that are accepted as legitimate are capable of securing resources to govern, to develop, and to compete in the international economic and political arena. Therefore, the central question in taxation, from the dictum of political development, is what the state must offer to earn citizen compliance. Citizens' demands vary with regimes and over time, but they include some combination of accountable institutions, material benefits, and cultural meaning (Campbell, 1993).

In most African and other developing countries, the social contract is notably weak, and at best applies to only a narrow segment of society. Lledo et al (2004:12) argued that many citizens are trapped within clientelist relations, informality, social exclusion, and other forms of marginality. Even if they make tax contributions and benefit from public expenditure, there is no notion of a contract between citizen and state. They pay only what they have to pay to avoid being audited and caught. In part, this is a result of the socioeconomic characteristics of the regions: large inequalities, a narrow middle class, limited education, low 
participation, oligarchic agricultural elites, highly politicised party system and a large informal sector. Political institutions bear some of the blame also, as they are incapable of penetrating society to extract resources, extend benefits to secure compliance, and generate the coalitions and embeddedness that create legitimacy and capacity.

\section{Literature Review}

Virtually all African countries have experienced catastrophic economic and political crises, leading inevitably to their inability to meet the delivery of basic needs and security to their citizens (Mkandawire, 2009). Recent developments across the continent seem to reinforce the position of Ake (1996), Olowu (2003), Brautigham (2008), Diamond (2008), and Owusu-Afriyie (2009) that economic circumstances determine governance directions. Elsewhere, the extent of the capacity to raise revenue from domestic sources in developing countries, of which taxes are essential, has also been sufficiently linked to good governance (Akanle, 1991; Munoz and Sang-Wook Cho 2003; Soest, 2007; Aberbach and Christensen, 2007; Ali-Nakyea, 2008; Kiabel and Nwokah 2009). Thus, it goes without saying that a country's source of revenue is an important component of her governance.

The situation in Nigeria is not unique in the African continent, though with different peculiarities. Nevertheless, the effects of the mono-cultural revenue base on governance have been largely similar. Many reasons have been ascribed to this trend. One is that most African countries lack the necessary diversified revenue base and the ability to harness and maintain a sound management of national resources for human and national development (Green, 1965; Ake, 1996; Brautigam, 2008). Because their economic fortunes have been largely monolithic: agrarian, natural resource-dependent, or aid propelled, most African countries have seen their fiscal fortunes fluctuate depending on monies from abroad. The driving force of the economies is therefore foreign-induced, and thus lacks the requisite home-grown force to propel the economies, which invariably conditions them to depend on foreign capitals. By implication, the countries lack the necessary independent economic tool to reposition their source of revenue in a way that, according to Olowu (2003), could galvanise the development of the basic infrastructural amenities for the general good of the citizens. As he rightly noted, more than anything, governments might be in a better position to impact positively on poverty through a more effective local level taxation, which he argued to include assurances for good governance.

Historically, economics and politics are inextricably linked; a development that is best showcased in the centrality of revenue in shaping the character of governance in many countries (Drake, 1972). Adam Smith (1776:345) argued, in his classic book The Wealth of Nations, that the first object of the political economy of a nation was to ensure a good source of stable 'plentiful revenue' Edmund Burke said 'the revenue of a state is the state' (Humphreys et al, 2007:257).. Levi (1988:1) stated that "the history of state revenue production is the history of the evolution of the state". It follows therefore that finding a good revenue source is at the root of the governance in any country. Yet, revenue alone is necessary but not sufficient to determine the trajectory or effectiveness of governance. Such revenue, according to a number of scholars, must be sufficient and stable in yield (Rosenstein-Rodan, 1943; Moore, 2004; Stevens, 2003; Karl, 1997), and not subject to external volatility (Bienen, 1984; Kubeyinje and Nezianya, 1999). Furthermore, it must also be capable of building responsive government and high public expectations in which citizens' contribution is enhanced (Brautigam, 2008), and not rooted in free source which can lead to slothfulness and private hoarding on the citizens' part and sharp practices on the part of government (Keynes, 1936; Diamond, 2008). All of these governance-friendly characteristics have been identified to be key to tax revenue, and vice versa (Brautigam, 2008).

Ultimately, the obligation to pay for smooth running of government also helps to legitimize the demands by citizens for improved services and accountability. Brautigam (2008) argued that when revenue does not depend on taxes raised from citizens and domestic businesses, there is less incentive for governments to be accountable considering the financial independence inherent in such situation. In other words, if governments are not dependent on citizen's contribution in form of taxes for their finance, they are much likely to be less accountable and responsive to the citizen, and have little incentive to build political and organisational capacity to negotiate and collect revenue and spend it effectively. The inevitable outcome is arbitrary governance and a weak state. This scenario, perhaps, distinguished the $18^{\text {th }}$ Century American rebels that declared "No taxation without representation" in Boston Harbor in 1776 (Kelly, 2008) and set the tone for advanced democracies to be built on periodic elections and an implicit 'social contract' linking them with government.

This problematic is exacerbated if the state in question is a resource or aid dependent one. The economic record of mineral-exporting countries has been generally as disappointing as Adam Smith had observed in the $18^{\text {th }}$ century that untold wealth is susceptible to creating 'inferior ranks of people'; a nation whose people are 'in general idle, dissolute, and poor' (Smith, 1776:284). This obviously connects with the observation of Jean Bodin, a $16^{\text {th }}$ century French philosopher who commented that: Men of a fat and fertile soil are most commonly effeminate and cowards; whereas paradoxically a barren country makes men temperate by necessity, and by consequence careful, vigilant and industrious (Stevens, 2003:5). John Maynard Keynes argued 
in the same direction that resourced countries often experienced 'extreme poverty' (Keynes, 1936:211). Paradoxically, oil exporting nations have done far less well than resource-poor countries when one considers the huge revenues accruing to oil-exporting countries since 1973 when oil prices almost quadrupled. Diamond (2008:74) submitted that "not even a single one" of the 21 countries whose economies are dominated by revenue from oil "is a democracy". According to him, oil states are deficient of the "connective tissues" to society that induce political accountability. Olomola and Adejumo (2006:28-33) demonstrated how 'oil price shock' affected Nigeria's economic governance by adversely impacting on macroeconomic activities like the general output level, inflation rate, money supply, and real exchange rate.

\section{Methodology}

This study utilized primary and secondary data sources. Primary data were collected through the conduct of in-depth interviews and focus group discussion with a cross section of the public as well as government officials involved in the collection and administration of tax revenues, while secondary data were collected through rigorous desk research. From the six geopolitical zones of Nigeria; Lagos State, Kaduna State and Rivers State from namely South-west, North-west, and South-south were purposively selected due to the potentials for revenue collection and historical and political development in their respective zones. From each of these states, government executives and leaders of a dominant local/communal institution were selected according to their past roles in the vanguard of their members and other records of political/economic agitation.

\section{Results and Discussion}

Data obtained from the revenue collection records of State governments of Nigeria shows that tax revenue is paltry. As Table 1 below shows, the percentage annual average of internally generated revenue to total revenue in two states, Kaduna and Rivers are about $4 \%$ and $8 \%$ respectively. The point would then lead to the reasoning that inadequacy of fund leads to lack of fund to tackle the challenges of meeting their burden of governance, most especially in so far as provision of social amenities and security are concerned. Also at the Federal level, the entire tax base of the economy is continually jeopadised by oil revenue, with its easy proceeds accruing torrentially directly to government coffers, and generated with minimum interaction with citizens in the form labour input. The effect of the large informal sector and the informalization of some formal activities have also contributed to low-returns on revenues in Nigeria. The CBN (2013) bulleting reports that the introduction of cashless economy that would allow closer monitoring of economic activities is in less than one-third of the states of the federation (see figure 1 below).

Analysis of the in-depth interview and the focus group discussions conducted on association and communal leaders across the selected states revealed that legitimacy crisis of successive governments in Nigeria is indeed critical to tax compliance. This predisposes that states that are accepted as legitimate are more likely to secure people-based revenue to govern and to develop as at when due or needed. It also indicates that a political atmosphere in taxation becomes a tool for negotiation of good governance indicators is likely to emerge between the state and the citizens. The analysis also shows the existence of many associations of local 'public' whose main aims center on the benefit to be derived from governments and limiting members' contributions to government coffers, most especially by way of taxes. Research evidence reveals that most times, the disagreement between associations and governments are on reduction/stoppage of certain taxes payable by members (see figure 2 below), thus undermining the capacity of the state to impose taxes as a civil responsibility on the part of the citizenry.

Except in the area of general public awareness undertaken by tax agencies for tax compliances and subtle campaigns for tax compliance using government projects sites as 'tax-payers' money in action' to dissuade the public from tax evasion or avoidance, there is no evidence of painstaking efforts by government executives to essentially change the prevailing tax culture of the citizens towards economic reliance on peoplecentered revenue base and/or eventual diversification from oil revenue.

\section{Conclusions}

There is no doubt that research into the nexus between taxation and governance is at low ebb in Africa despite its dwindling revenue profile, the global financial crisis afflicting revenue bases of the states and the settled condition of taxation as a veritable governance issue in the advanced world. Yet, the centrality of taxation to good governance- encompassing the capacity, responsiveness and accountability of government- can no longer be underestimated. In the realm of capacity, taxation provides sustainable foundation, unlike resource revenue, for the provision of public goods and the implementation of effective public policies. Also, taxation is the avenue through which citizens are able to connect with government; and an important catalyst for public demands for responsiveness and accountability. However, there is the awareness among the citizens on taxation, not only as an important element of enduring public finance but also as a means by which citizens, through 
forming of associations and pressure groups, ensure the limitation of their commitment to contribute into the revenues of the state if the government is perceived lacking in political legitimacy and good governance.

\section{References}

[1]. Aberbach, J. D. \& Christensen, T. (2007). "The challenges of modernising tax administration: putting customers first in coersive public organisation". Public Policy and Administration, 22(2), 155-182.

[2]. Akanle, O. (1991). Tax law and tax administration in Nigeria. Lagos: Nigerian Institute of Advanced Legal Studies (NIALS)

[3]. Ake, C., (1999), "Shelling Nigeria Ablaze," Tell, January 29, 1999, p. 34.

[4]. Ali-Nakyea, A. (2008). Taxation in Ghana: principles, practice and planning ( $2^{\text {nd }}$ Ed.). Accra: Black Mask Ltd.

[5]. Ascher, W. (1989) Risk, Politics, and Tax Reform: Lessons from Some Latin American Experiences. In M. Gillis (ed.), Tax reform in developing countries. North Carolina: Duke University Press.

[6]. Backhaus, J. (2002). Fiscal Sociology: What for? American Journal of Economics and Sociology, 61(1), 61-73.

[7]. Bates, R. (1989). A Political Scientist Looks at Tax Reform. In M. Gillis (ed.), Tax reform in developing countries. North Carolina: Duke University Press.

[8]. Besley, T., \& Case, A. (2002). "Political institutions and policy outcomes". Journal of Economic Literature, 41(1), 56-73.

[9]. Bienen, H., (1984), "Oil Revenue and Policy Change in Nigeria", World Bank Staff Working Paper SWP 592, IBRD/World Bank, Washington, D.C., USA

[10]. Brautigam, D., (2008). "Taxation and Governance in Africa: Take a Second Look", Working Paper, IMF

[11]. Brennan, G., \& Buchanan, J. M. (1980). The power of tax: analytical foundations for a fiscal constitution. Cambridge: Cambridge University Press.

[12]. Buchanan, J. M. (1987). "Constitutional economics". In P. Newman (ed.), The new Palgrave dictionary of Economics, London: Macmillan

[13]. Campbell, J. L. (1993). "The state and fiscal sociology". Annual Review of Sociology, 19, 163-185.

[14]. Diamond, L. (2008). The spirit of democracy: the struggle to build free societies throughout the world. New York: Holt Paperback.

[15]. Drake, P. (1972). "Natural Resources versus Foreign Borrowing in Economic Development". Economic Journal, 82(327), 951962

[16]. Duruji, M. M., (2010). "Ethnic Militias And Sub-Nationalism In Nigeria: A Comparative Study Of MASSOB and OPC". Ph.D. Thesis Covenant University, Nigeria: Accessed eprints.covenantuniversity.edu.ng/695/.../PhD\%20Thesis\%20Cover.d...21/03/12

[17]. Green, R. A. (1965). "Four African development plans: Ghana, Kenya, Nigeria and Tanzania". The Journal of Modern African Studies, 3(2), 249-279.

[18]. Humphreys, M., Sachs, J. \& Stiglitz, J. E. (2007). Escaping the Resource Curse. W.DC: Collumbia University Press

[19]. Institute for Social Development (UNRISD), July Issue

[20]. Karl, T. L. (1997). The paradox of plenty: oil booms and petro-states. Berkeley: University of California Press.

[21]. Keynes, J. M. (1936). The General Theory of Employment, Interest and Money. An eBook downloaded from www.gutenberg.net, December 2009

[22]. Kiabel, B. D. \& Nwokah, N. G. (2009). "Boosting revenue generation bt state governments in Nigeria: the tax consultants option revisited". European Journal of Social Sciences, 8(4), 532-539

[23]. Kubeyinje, K., \& Nezianya, T. (1999). "Oil: a mixed blessing for Nigerian economy". African Recovery, 13(1), 10-29.

[24]. Levi, M. (1988). Of rule and revenue. Berkeley: University of California Press.

[25]. Lledo, V., Schneider, A. and Moore, M., (2004), "Pro-poor Tax Reform in Latin America: A Critical Survey and Policy Recommendations," Institute of Development Studies, University of Sussex

[26]. Miller, J. (2007). "Wherefore the liberal state? Post-soviet democratic blues and lessons from fiscal sociology". East European Politics and Societies, 21(3), 294-315.

[27]. Mkandawire, T. (2009). "Institutional Monocropping and Monotasking in Africa, Democracy, Governance and Well-Being Programme", Paper Number 1, United Nations Research

[28]. Moore, M. (2004). "Taxation and the political agenda: north and south". Development Studies, June(1), 56-81

[29]. Mumford, A. (2008). "Towards a fiscal sociology of tax credits and the fathers' rights movement". Social and Legal Studies, 117 , 217-236.

[30]. Munoz, S. and Sang-Wook Cho, S., (2003). Social Impacts of Tax Reforms: The Case of Ethiopia, IMF Working Paper $\mathrm{WP} / 03 / 232, \mathrm{IMF}$

[31]. Nigerian Institute of Advanced Legal Studies (NIALS), (2010). "Roundtable on Strike and Collective Bargaining in Nigeria": Accessed from http://www.nials-nigeria.org/round tables/29th july 10 RoundtableCommuniqueonStrikandColl\% 20 Bargaining.pdf 21/03/12

[32]. Olaiya, T. A. (2012). Tax Administration and Burden of Governance in Nigeria and Ghana: A Comparative Analysis. Germany: Lap-Lambert Academic Publishing.

[33]. Olomola, P. A. \& Adejumo, A. A. (2006). Oil price shock and macroeconomic activities in Nigeria. International Research Journal of Finance and Economics - Issue 3, 28-34

[34]. Olowu, D. (2003). "Local Democracy, Taxation and Multi-Level Governance in Africa", Draftpaper prepared for Norwegian Association for Development Research (NFU) Annual Conference on Politics and Poverty, Oslo, Norway

[35]. Owusu-Afriyie, E., (2009). "An Assessment of Impact of Tax Reforms on the Tax System of Ghana”, (Monetary Policy Analysis and Financial Stability Department) Bank of Ghana Working Paper WP/BOG-2009/01

[36]. Rosenstein-Rodan, P. (1943). "Problems of Industrialisation of Eastern and South-Eastern Europe". Economic Journal, 53, 56-83

[37]. Smith, A. (1776). The wealth of nations. Introduction by A. Krueger (2003), with notes and marginal summary by Edwin Canaan. London: Blackwell Publishing Ltd.

[38]. Soest, C. V. (2007). "Measuring the capability to raise revenue: process and output dimensions and their application to the Zambia revenue authority". Public Administration and Development, 27, 353-365

[39]. Stevens, P., (2003). Resource Impact - Blessing or Curse. A Literature Survey for IPIECA Downloaded in December 2010 from http://www.dundee.ac.uk/cepmlp/journal/html/Vol13/article13-14.pdf

Table 1: Showing Relative Percentage of Internally Generated Revenue (IGR) to Total Revenue in Kaduna and Rivers States of Nigeria from $1999-2013$ 


\begin{tabular}{|l|l|l|}
\hline Years/State & Kaduna State & Rivers State \\
\hline $\mathbf{1 9 9 9}$ & $0.3 \%$ & $6.7 \%$ \\
\hline $\mathbf{2 0 0 0}$ & $3.3 \%$ & $7.7 \%$ \\
\hline $\mathbf{2 0 0 1}$ & $3.8 \%$ & $4.3 \%$ \\
\hline $\mathbf{2 0 0 2}$ & $4.2 \%$ & $10.2 \%$ \\
\hline $\mathbf{2 0 0 3}$ & $6.1 \%$ & $8.9 \%$ \\
\hline $\mathbf{2 0 0 4}$ & $4.2 \%$ & $6.7 \%$ \\
\hline $\mathbf{2 0 0 5}$ & $6.0 \%$ & $6.3 \%$ \\
\hline $\mathbf{2 0 0 6}$ & $3.2 \%$ & $7.8 \%$ \\
\hline $\mathbf{2 0 0 7}$ & $3.3 \%$ & $8.2 \%$ \\
\hline $\mathbf{2 0 0 8}$ & $3.8 \%$ & $8.9 \%$ \\
\hline $\mathbf{2 0 0 9}$ & $3.4 \%$ & $7.2 \%$ \\
\hline $\mathbf{2 0 1 0}$ & 3.6 & 7.1 \\
\hline $\mathbf{2 0 1 1}$ & 3.9 & 7.6 \\
\hline $\mathbf{2 0 1 2}$ & 4.1 & 6.9 \\
\hline $\mathbf{2 0 1 3} * *$ & 4.3 & 8.0 \\
\hline $\begin{array}{l}\text { Total Percentage } \\
\text { Average }\end{array}$ & $\mathbf{3 . 8 1} \%$ & $\mathbf{7 . 5 0} \%$ \\
\hline Source: SBIR Offo & \\
\hline
\end{tabular}

Source: SBIR Offices in Kaduna and Rivers States of Nigeria, 2014

*The above is without respect to Derivation allocation to Rivers State, which receives monthly allocation along with other oil-producing States.

** Estimated

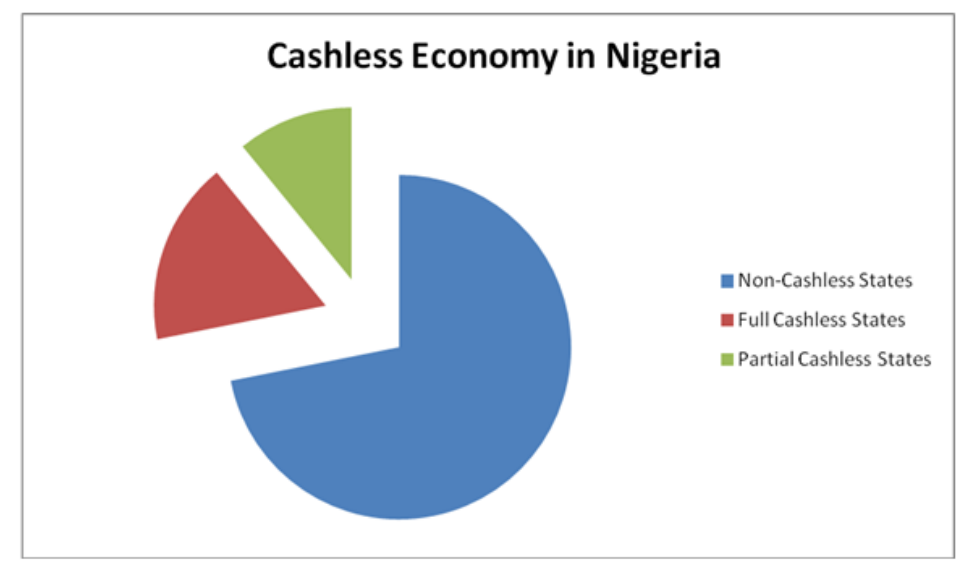

Figure 1 Pie Chart showing the state of Cashless Economy in Nigerian States Source: Central Bank of Nigeria Bulletin, 2013

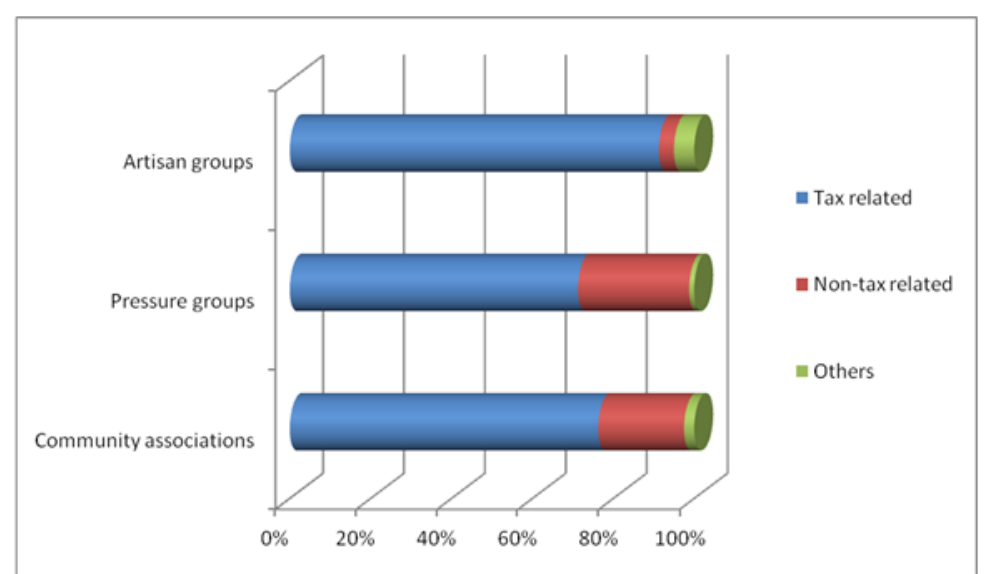

Figure 2: Bar chart showing No. of strike actions embarked upon against government per tens Source: Field Data, 2014 